\title{
Dinophysis acuta in Scottish Coastal Waters and Its Influence on Diarrhetic Shellfish Toxin Profiles
}

\author{
Sarah C. Swan 1,*(D), Andrew D. Turner ${ }^{2}$, Eileen Bresnan ${ }^{3}$, Callum Whyte ${ }^{1}{ }^{\mathbb{D}}$, Ruth F. Paterson ${ }^{1}$, \\ Sharon McNeill ${ }^{1}$, Elaine Mitchell ${ }^{1}$ and Keith Davidson ${ }^{1}$ \\ 1 Scottish Association for Marine Science, Scottish Marine Institute, Oban, Argyll PA37 1QA, UK; \\ callum.whyte@sams.ac.uk (C.W.); ruthflo.paterson@gmail.com (R.F.P.); sharon.mcneill@sams.ac.uk (S.M.); \\ elaine.mitchell@sams.ac.uk (E.M.); keith.davidson@sams.ac.uk (K.D.) \\ 2 Centre for Environment, Fisheries \& Aquaculture Science, The Nothe, Barrack Road, Weymouth, \\ Dorset DT4 8UB, UK; andrew.turner@cefas.co.uk \\ 3 Marine Scotland Science, Marine Laboratory, 375 Victoria Road, Aberdeen AB11 9DB, UK; \\ eileen.bresnan@gov.scot \\ * Correspondence: sarah.swan@sams.ac.uk; Tel.: +44-(0)1631-559-000
}

Received: 21 August 2018; Accepted: 26 September 2018; Published: 28 September 2018

\begin{abstract}
Diarrhetic shellfish toxins produced by the dinoflagellate genus Dinophysis are a major problem for the shellfish industry worldwide. Separate species of the genus have been associated with the production of different analogues of the okadaic acid group of toxins. To evaluate the spatial and temporal variability of Dinophysis species and toxins in the important shellfish-harvesting region of the Scottish west coast, we analysed data collected from 1996 to 2017 in two contrasting locations: Loch Ewe and the Clyde Sea. Seasonal studies were also undertaken, in Loch Ewe in both 2001 and 2002, and in the Clyde in 2015. Dinophysis acuminata was present throughout the growing season during every year of the study, with blooms typically occurring between May and September at both locations. The appearance of $D$. acuta was interannually sporadic and, when present, was most abundant in the late summer and autumn. The Clyde field study in 2015 indicated the importance of a temperature front in the formation of a D. acuta bloom. A shift in toxin profiles of common mussels (Mytilus edulis) tested during regulatory monitoring was evident, with a proportional decrease in okadaic acid (OA) and dinophysistoxin-1 (DTX1) and an increase in dinophysistoxin-2 (DTX2) occurring when D. acuta became dominant. Routine enumeration of Dinophysis to species level could provide early warning of potential contamination of shellfish with DTX2 and thus determine the choice of the most suitable kit for effective end-product testing.
\end{abstract}

Keywords: Dinophysis; HAB monitoring; DSP toxins; aquaculture; shellfish toxicity; human health; time-series; seasonality; Scotland

Key Contribution: Long-term variation in seasonality and abundance of Dinophysis spp.; association with specific toxins in bivalve shellfish and potential impact on industry.

\section{Introduction}

Naturally occurring harmful algal blooms (HABs) are known to have an adverse effect on shellfish industries worldwide, with toxic contamination of shellfish from these events potentially resulting in both human illness and a detrimental impact on the often-fragile economies of rural areas [1]. Despite regulatory monitoring, the accumulation of toxins in shellfish has led to occasional reports of sickness, with relatively infrequent outbreaks of phytoplankton-generated Diarrhetic Shellfish Poisoning (DSP) around Europe and elsewhere since it was first reported from The Netherlands in the 1960s [2-4]. 
In the UK, DSP was associated with the ingestion of imported mussels (Mytilus spp.) in 1994 and with UK common (blue) mussels (Mytilus edulis) obtained from an unauthorised site in 1997 [5-7]. Common (blue) mussels harvested in Scotland were also linked to 159 cases of DSP in 2006 [8,9] and a further 70 reported cases in 2013 [10]. While these events are relatively few in number, their impact on consumer confidence and industry sustainability is significant.

To mitigate the risk of human illness caused by the consumption of contaminated shellfish, European Union regulations require EU Member States to have regulatory programmes in place to monitor the presence of both marine biotoxins in shellfish production areas and the causative phytoplankton [11]. In the UK, toxin testing of shellfish tissue is supported by the analysis of seawater samples for the presence of toxin-producing phytoplankton and results delivered by the monitoring programmes are used to make decisions regarding the opening and closure of classified shellfish harvesting areas. In Scotland, this information is also used by the aquaculture industry to make informed decisions, following guidance issued to harvesters by Food Standards Scotland (FSS) in 2014 [12], which may lead to either an increase in end-product testing to ensure the safety of shellfish placed on the market, or a voluntary cessation of harvesting.

Between 2012 and 2017, an average of over 2700 tests have been carried out each year on bivalves, around $70 \%$ of which were common (blue) mussels, collected from approximately 80 classified shellfish harvesting areas in Scottish coastal waters. One of the main causes for concern is the presence of lipophilic toxins, some of which cause DSP. The accumulation of these toxins in shellfish is a major problem for the aquaculture industry in Scotland. Since routine monitoring for these toxins began in 1998 using the mouse bioassay (MBA) [13], extensive harvesting closures that can last for several months in some areas have been enforced. The DSP toxins include okadaic acid (OA) and the dinophysis toxins, dinophysistoxin-1 (DTX1) and dinophysistoxin-2 (DTX2), henceforth referred to as the OA group toxins. The group collectively known as DTX3 are derivatives of OA, DTX1 and DTX2, esterified with saturated and unsaturated fatty acids [9] and the chemical structure of these toxins is described in detail elsewhere $[9,14]$. The relative potency of the toxins within the OA group differs, with the toxic potential of DTX1 being similar to that of OA, although both are more toxic than DTX2 [9]. Hence, a Toxicity Equivalency Factor of 0.6 is used for DTX2. The use of the MBA method meant that individual OA group toxins could not be routinely identified and previous information on the presence of these toxins came from research studies using LC-MS $[13,15]$. The introduction of LC-MS/MS methodology into the regulatory toxin testing in July 2011 provided the scope to assess the presence of this toxin group on a regional and temporal scale [16]. The OA group toxins are responsible for most of the toxin contamination in Scottish bivalves and the maximum permitted level (MPL) in harvestable shellfish is $160 \mu \mathrm{g}$ okadaic acid equivalent per $\mathrm{kg}$ shellfish flesh (OA eq. $/ \mathrm{kg}$ ) [9]. The percentage of shellfish tissue samples with OA group toxicity reported above the regulatory limit fluctuates by year [16] and between 2012 and 2017, it varied between 2.2\% (in 2017) and 11.5\% (in 2013), with annual maximum amounts of total OA group equivalent toxicity ranging from $694 \mu \mathrm{g}$ OA eq. $/ \mathrm{kg}$ in 2017 to $4993 \mu \mathrm{g}$ OA eq. $/ \mathrm{kg}$ in 2013. The exceptionally high toxin maximum from a production area in the Shetland Islands in 2013 resulted in an outbreak of DSP [10].

A number of causative phytoplankton species are associated with lipophilic toxins and those connected with the OA group toxins belong to the order Dinophysiales and include the genera Dinophysis Ehrenberg and Phalacroma Stein. Algal cells in this order are routinely identified using light microscopy in regulatory monitoring programmes. In Scottish waters they are currently reported as total Dinophysis spp. with an 'alert' threshold set at 100 cells/L, to ensure testing of shellfish for the presence of biotoxins. The species concept within Dinophysis is not clearly defined [17,18] and a certain amount of gradation in character traits can lead to morphological ambiguity. Differences in cell shape and size have been attributed to geographic variation, environmental selection, feeding behaviour and life cycle [19]. Stern et al. [18] examined the genetic sequences of cells from Scottish coastal waters with morphologies that appeared to belong to the D. acuminata complex and identified the presence of both D. acuminata Claparéde \& Lachmann and D. ovum and also confirmed the dominance of $D$. 
acuminata during late spring/summer. The other main species observed is D. acuta Ehrenberg but with considerable interannual variability in abundance [1]. Blooms dominated by D. acuta have occasionally been recorded, as was the case for 2001 and 2002 in Scapa Bay in Orkney [13]. Dinophysis dens is sometimes observed at low concentrations in blooms of D. acuta and is now regarded as a life-stage of D. acuta $[20,21]$. Phalacroma rotundatum is also regularly detected around the Scottish coast but again at low concentrations rarely exceeding 100 cells/L. Although it has been found to contain toxins, there is some evidence that it may not be a toxin-producer itself but may instead act as a vector [22].

Another known producer of diarrhetic shellfish toxins (DSTs) is the benthic dinoflagellate Prorocentrum lima. This species is detected more often in the sandy sediments of shallow bays where oyster cultivation takes place, although it can also grow epiphytically [23]. Prorocentrum lima is recorded sporadically in integrated water column samples but cell counts are likely to be underestimated using this method and it is generally more frequently observed in samples obtained by bucket. Analysis of the data obtained through the Scottish monitoring programme failed to establish a clear link between the presence of DSP toxins in bivalve molluscs and the abundance of P. lima (Scottish Association for Marine Science (SAMS) unpublished data). Hence this study is focused on the apparent link between DSTs in shellfish and the presence of Dinophysis.

In order to understand variability within the Dinophysis population and its influence on toxin accumulation in bivalve molluscs, this study was undertaken to investigate the annual and seasonal variation of Dinophysis spp. and associated toxins in two important shellfish harvesting regions on the west coast of Scotland, Loch Ewe and the Firth of Clyde (Figure 1). Hence, the risks to human health associated with changes in species composition of blooms can be evaluated.

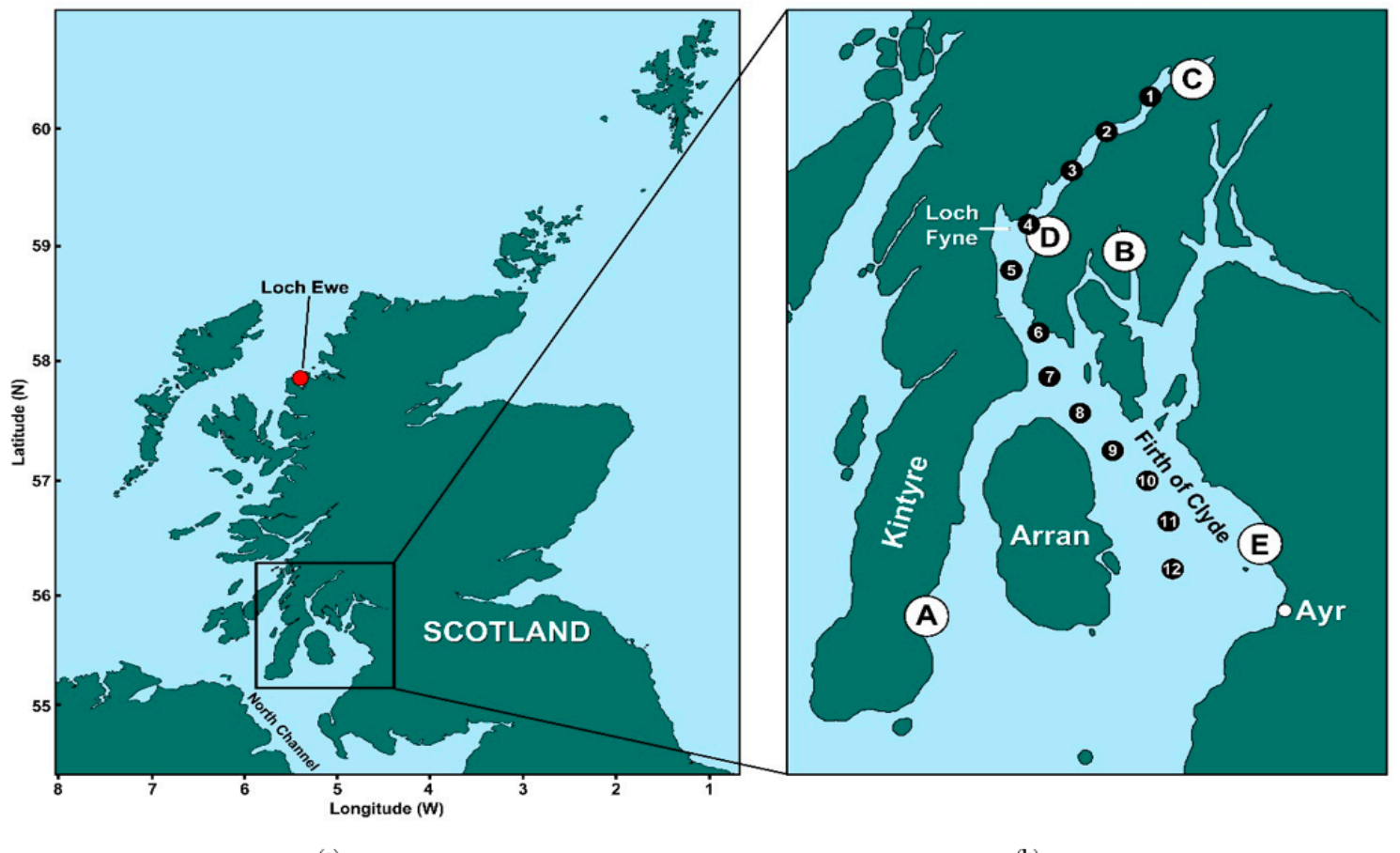

(a)

(b)

Figure 1. Maps of Scotland (a) and the study area showing the location of the Firth of Clyde and the official control monitoring sites for phytoplankton and shellfish $(\mathbf{b})$, indicated by the white circles $(\mathrm{A}=$ Campbeltown Loch, B = Loch Striven, C = Loch Fyne: Ardkinglas, D = Loch Fyne: Otter Ferry and $\mathrm{E}=$ Barassie). Mussels are harvested at sites A, B and C, Pacific oysters at site D and razor clams at site E. The black circles (numbered 1 to 12 ) show the location of the additional phytoplankton samples obtained from the research survey conducted in early September 2015. The location of the long-term monitoring site at Loch Ewe is indicated in (a). 


\section{Results}

\subsection{Loch Ewe}

\subsubsection{Dinophysis Abundance}

The abundance of Dinophysis in Loch Ewe between 1996 and 2017 varied considerably by month and between years. Dinophysis acuminata was recorded during the phytoplankton growing season (spring/summer) every year and in some instances during the winter months as well. Counts at or exceeding the 'alert' threshold that triggers shellfish toxin testing (100 cells/L) were obtained from March to November but the species was typically most abundant between May and August (Figure 2a). By contrast, D. acuta was never recorded between January and March, was detected above the 'alert' threshold from May to September but was most abundant between July and September (Figure 2b), with $D$. acuminata cells often present in the community at the same time. Bloom densities were not consistent between years, with $D$. acuminata typically recorded at maximum annual densities of less than 3000 cells / L but with some notable blooms in 2003, 2015 and 2016, when cell densities reached 4940 cells/L, 9540 cells/L and 24,340 cells/L, respectively. Dinophysis acuta was generally much less abundant, apart from an increase in cell densities between 1999 and 2002, including an exceptional bloom of 8040 cells / L recorded in August 2000.

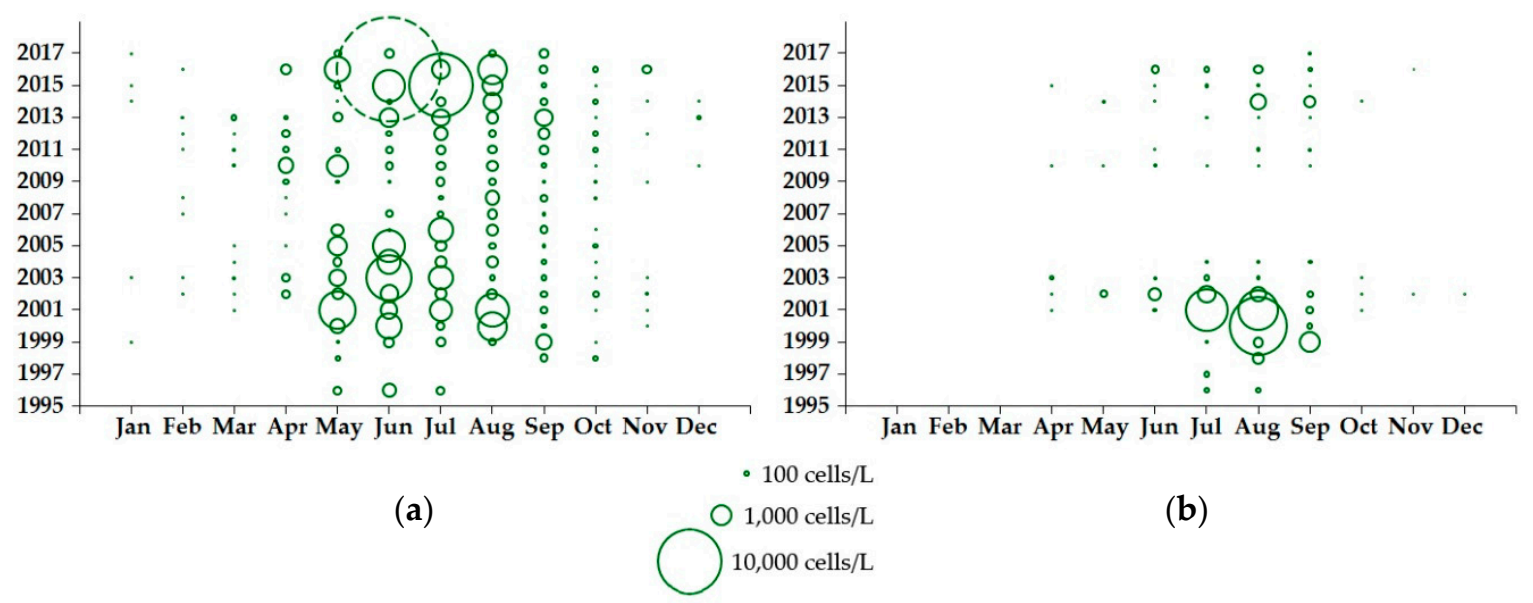

Figure 2. Maximum abundance by month for (a) D. acuminata and (b) D. acuta in phytoplankton samples obtained from Loch Ewe (NW Scotland) between 1996 and 2017, based on the analysis of 1797 records. The dashed circle in (a) represents a dense bloom of D. acuminata recorded in Loch Ewe in 2016 (24,340 cells/L).

\subsubsection{Toxin Concentration in Shellfish}

LC-MS analysis was carried out on samples of common mussel tissue obtained from Loch Ewe in 2001 and 2002, coinciding with blooms of Dinophysis. For the 2001 investigation, DTX1 and DTX2 were recorded as being either present or absent, although OA was quantified. Weekly sampling occurred in 2001 and OA group toxins were detected in mussels, with the concentration of OA reaching a maximum value of $141 \mu \mathrm{g} / \mathrm{kg}$ in early June (week 22), associated with a bloom of D. acuminata of density 2980 cells/L in the preceding week (Figure 3). DTX2 was recorded as absent until early August (week 31), following a bloom of D. acuta at a density of 3900 cells/L in mid July (week 29). DTX1 was only detected on one occasion, also in week 31. In 2002 the sampling frequency in Loch Ewe was increased to twice a week. Both species of Dinophysis were less abundant, although D. acuminata levels began to increase from around mid May, reaching a maximum value of 573 cells / L in mid June (week 25), whereas D. acuta reached a maximum abundance of 447 cells / L in early August (latter half of week 31) (Figure 4a). Okadaic acid was detected in mussels in every week continuously from late May until mid October but DTX1 was infrequently detected and mostly occurred in June when D. acuminata 
was the dominant species (Figure 4b). DTX2 was more associated with D. acuta (Figure 4d) and was absent until mid July (latter half of week 28), reaching a maximum value of $186 \mu \mathrm{g} / \mathrm{kg}$ one week after the D. acuta bloom peak of 447 cells/L. The apparent delay in toxin accumulation in the mussels following the Dinophysis blooms (Figure 4c,d) was investigated using a non-parametric Spearman's Rank-Order Correlation. The relationships between the individual toxins, OA and DTX2 and the abundance of both D. acuminata and D. acuta were explored over time, with lags of between 0 and 3 weeks at half-weekly intervals. A strong positive correlation was identified between D. acuminata and OA throughout the bloom period, reaching a maximum value with a two-week lag $\left(r_{\mathrm{s}}=0.815\right.$, $p<0.001$ ). We found no significant correlation between D. acuminata and DTX2. A strong positive correlation was also identified between D. acuta and OA throughout the bloom period but as both $D$. acuminata and D. acuta were present at the same time throughout most of the summer, it is difficult to discriminate the toxin contribution from each individual species. However, D. acuta was significantly correlated with DTX2, reaching a maximum value with a lag of 1.5 weeks $\left(r_{\mathrm{s}}=0.569, p<0.001\right)$.

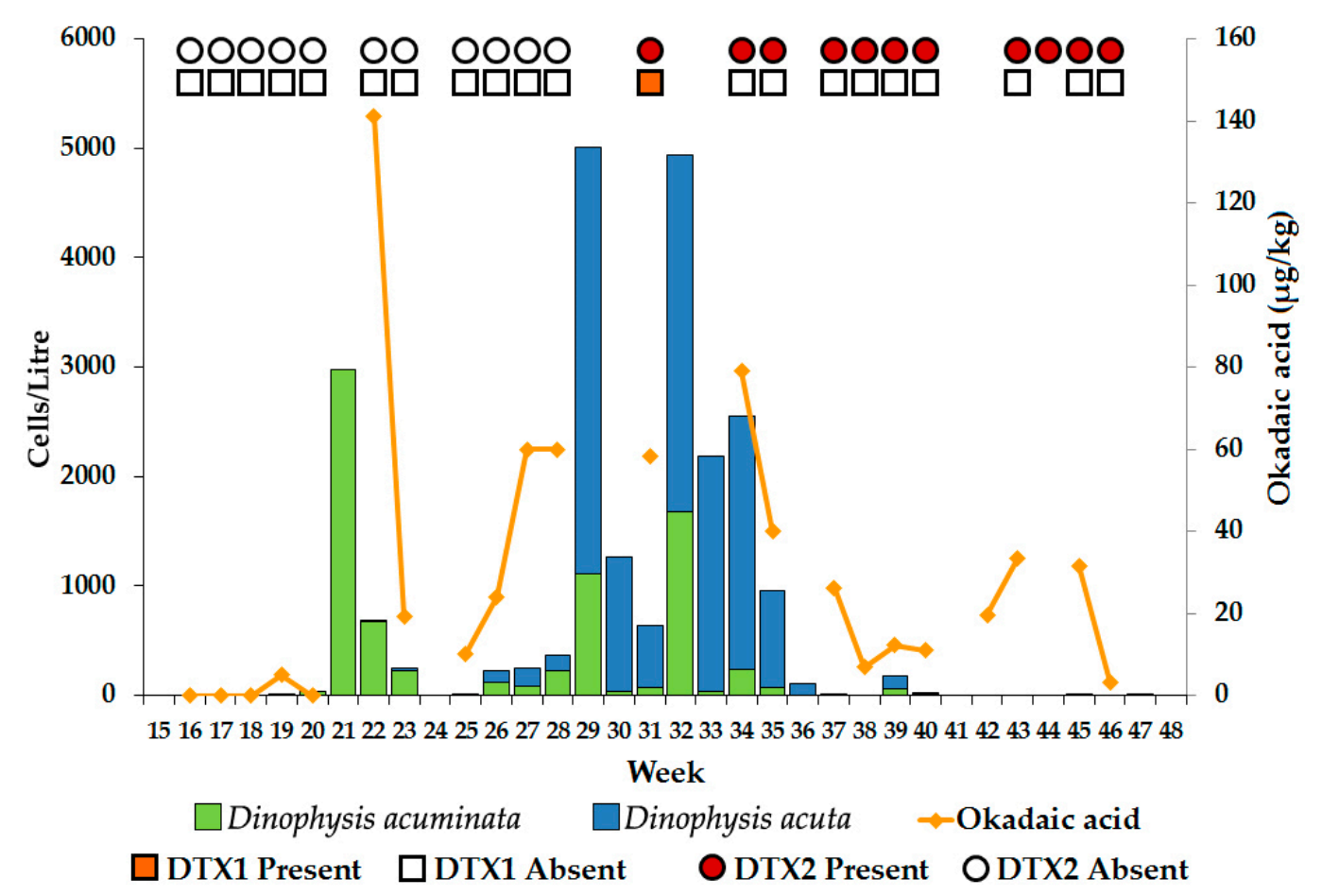

Figure 3. Stacked bar chart showing the abundance of D. acuminata and D. acuta and okadaic acid in common mussels from Loch Ewe during 2001. Cell counts were averaged for triplicate sub-samples every week. DTX1 and DTX2 were recorded as being either present or absent and are indicated by symbols. 

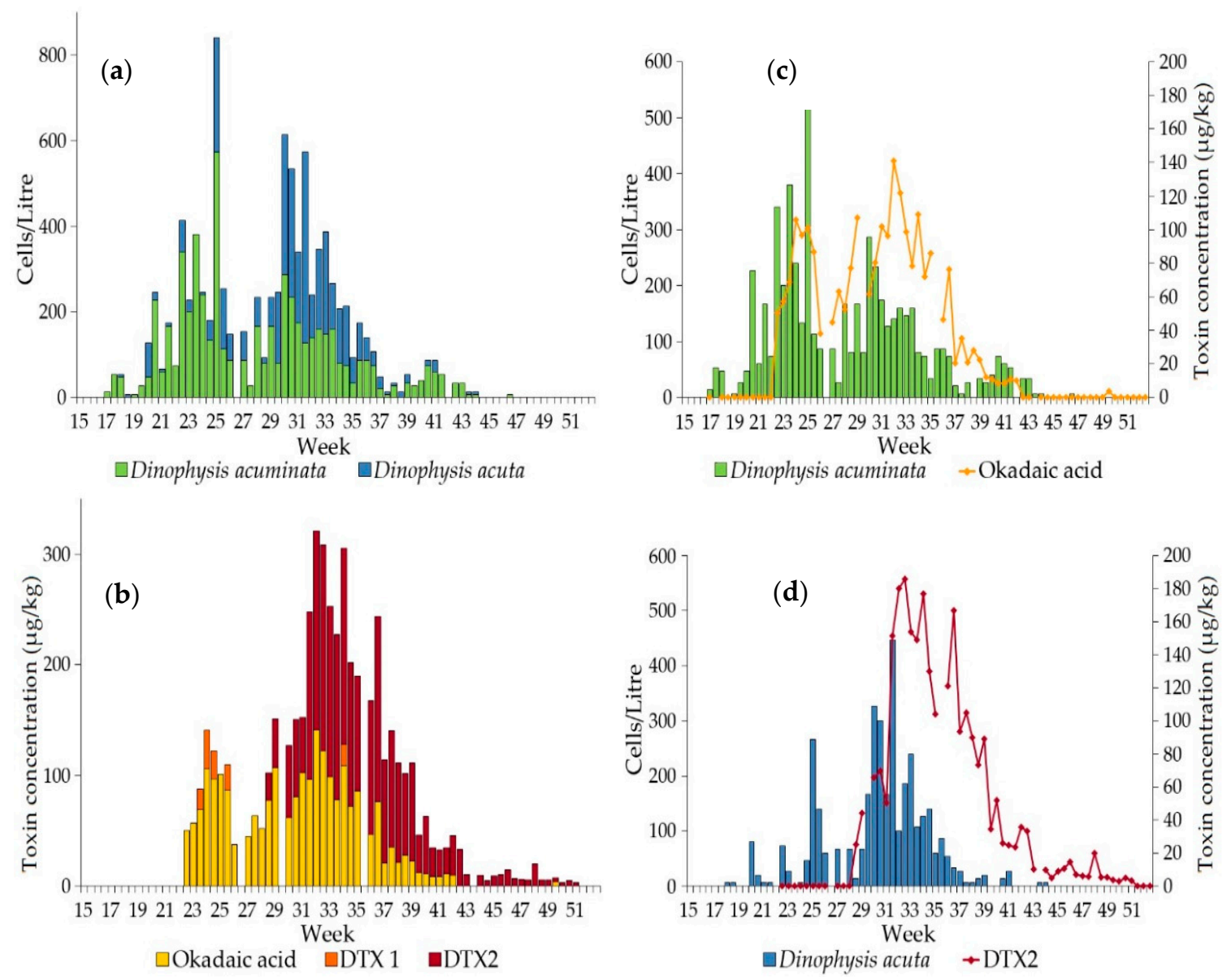

Figure 4. Abundances of D. acuminata and D. acuta in Loch Ewe during 2002 are shown in (a). Cell counts were averaged from triplicate sub-samples collected twice a week. Toxin concentrations in common mussels for the corresponding weeks are shown in (b). The relationships between $D$. acuminata and OA and between D. acuta and DTX2 are shown in (c,d), respectively.
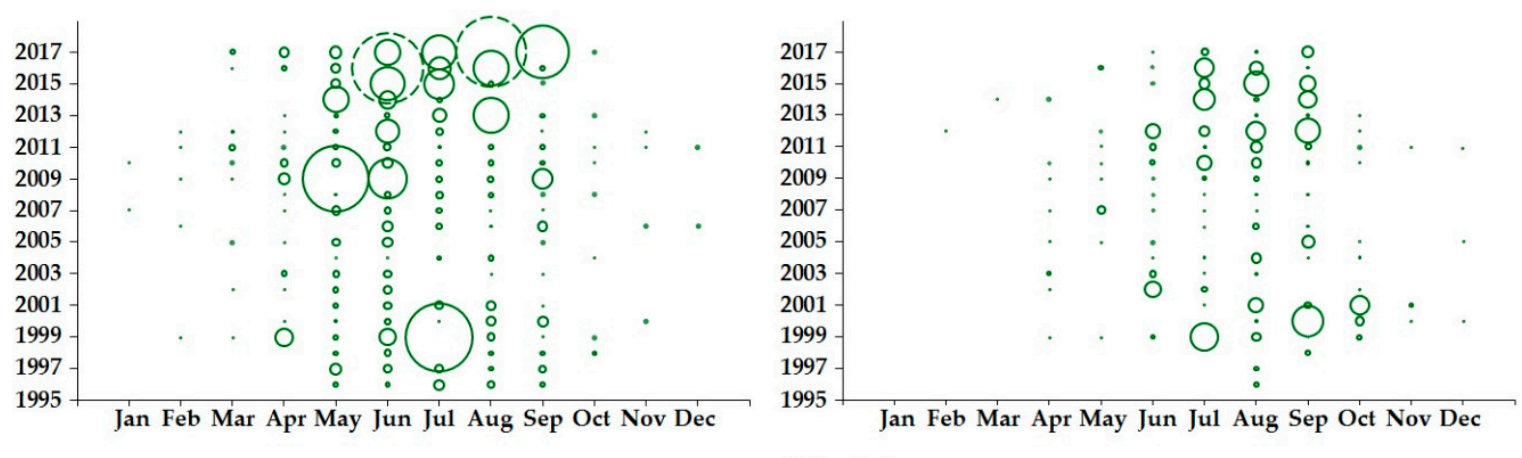

- 100 cells/L

(a)

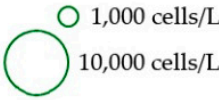

(b)

Figure 5. Maximum abundance of (a) D. acuminata and (b) D. acuta recorded at monitoring sites around the Firth of Clyde between 1996 and 2017, based on the analysis of 1001 records from eight sampling locations. The dashed circles in (a) represent dense blooms of D. acuminata observed in Loch Fyne: Ardkinglas (Site C in Figure 1b) in 2016 (85,760 cells/L) and 2017 (180,289 cells/L). 

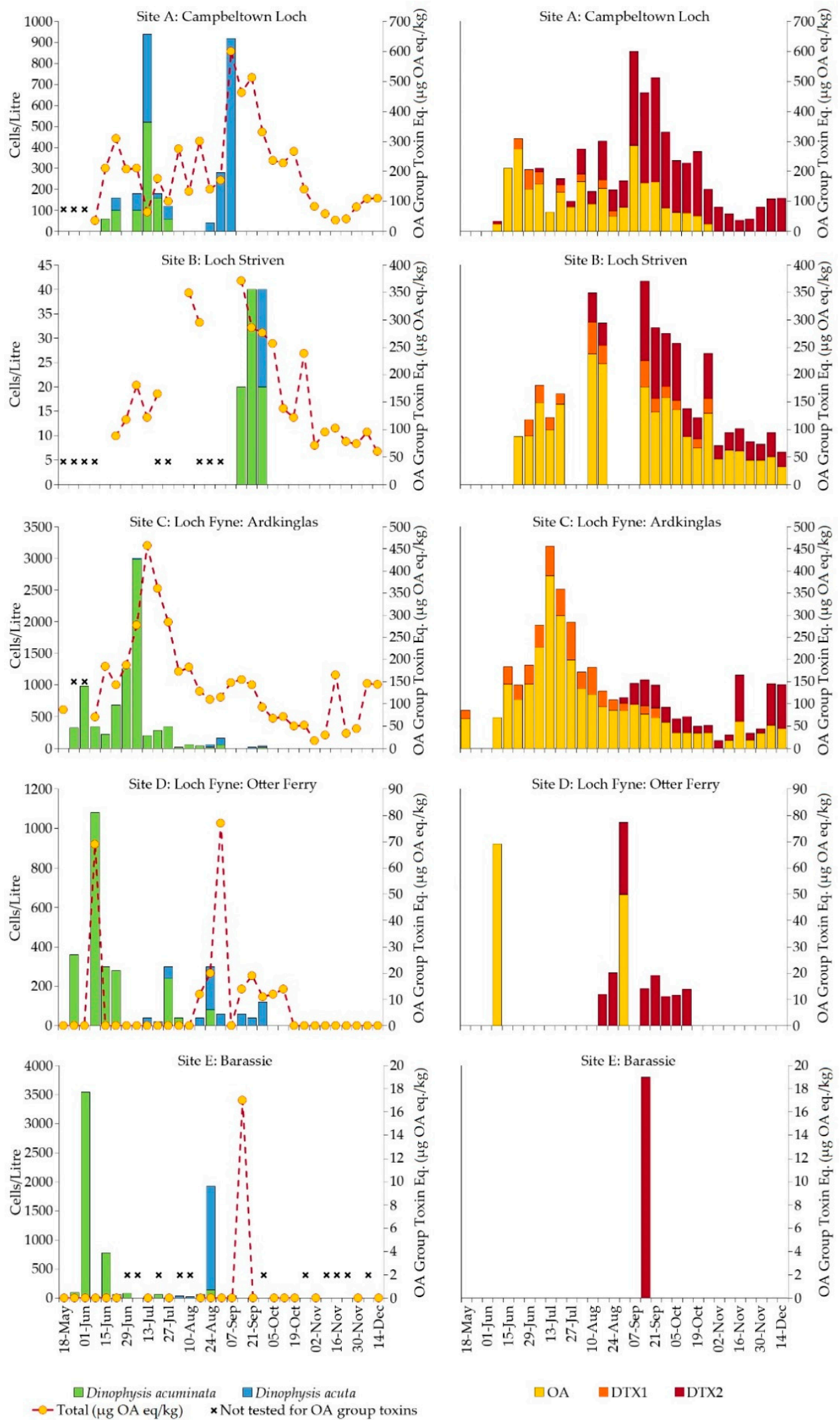

Figure 6. Left hand column shows the abundance of D. acuminata and D. acuta at official control monitoring sites and total OA group toxin equivalent (yellow circles) detected in shellfish between May and December 2015. Right hand column shows the contribution of OA, DTX1 and DTX2 (including esters) to the total OA group value (Toxicity Equivalency Factor of 0.6 applied to DTX2). No testing for lipophilic toxins was performed in late May and early June at the three mussel sites (A, B and C) due to the presence of paralytic shellfish toxins above the regulatory limit. 


\subsection{Firth of Clyde}

\subsubsection{Dinophysis Abundance}

Time-series data collected between 1996 and 2017 from eight sampling locations around the Firth of Clyde and associated sea lochs showed a greater variability in D. acuminata abundance (Figure 5a). As in Loch Ewe, this species was detected in every month of the year, although this was not the case for every year and with above 'alert' threshold events from March to October. Some exceptionally dense blooms were observed in 1999, 2009, 2016 and 2017, with recorded cell densities of 13,860 cells/L, 13,260 cells/L, 85,760 cells/L and 180,289 cells/L, respectively. Apart from the 1999 bloom recorded in Loch Striven (Figure 1b, site B), the other dense blooms were all detected in upper Loch Fyne: Ardkinglas (Figure 1b, site C). Dinophysis acuta in the Firth of Clyde (Figure 5b) showed a similar profile to that in Loch Ewe, with cell counts also highest between July and September. Interannual variability was evident, with the densest $D$. acuta blooms occurring between 1999 and 2002 and again between 2012 and 2016, coinciding with an increase in D. acuta blooms further north in Loch Ewe.

A detailed examination of data obtained from the regulatory monitoring sites around the Firth of Clyde in 2015 also showed distinct patterns of abundance and seasonality for D. acuminata and D. acuta (Figure 6). Phytoplankton counts identified a bloom of predominantly D. acuminata widespread throughout the area from late May into mid July 2015. The highest recorded densities were 3540 cells/L at Barassie (Site E) on 2 June, 1080 cells/L at Loch Fyne: Otter Ferry (Site D) on 9 June and 2980 cells/L further up Loch Fyne at Ardkinglas (Site C) on 7 July. During this early part of summer at most of the sites, the Dinophysis population was exclusively D. acuminata. However, a mixed bloom of D. acuminata and D. acuta was observed in Campbeltown Loch (Site A) on 13 July, with cell abundances of 520 and 420 cells/L, respectively. Subsequently, D. acuta dominated the Dinophysis in Campbeltown Loch, reaching a maximum of 920 cells/L on 7 September. An increase in the abundance of D. acuta was also noted at all the other monitoring sites from around mid August, with a maximum bloom density of 1780 cells/L detected at Barassie on 25 August. Although regulatory phytoplankton monitoring did not begin in Loch Striven (Site B) until 15 September and Dinophysis counts throughout the whole area were relatively low by this time, many empty D. acuta theca were observed, indicating that the bloom had extended into Loch Striven in the preceding weeks.

Data from the September 2015 research cruise in the Firth of Clyde were consistent with the phytoplankton data from the regulatory monitoring sites. Figure 7 a shows that $D$. acuminata was not particularly abundant in the samples from the cruise transect, with a maximum density of 200 cells/L recorded at Stations S7 and S11, to the seaward side of a marked temperature front between stations S6 and S7 [24]. The front was characterized by a body of cooler water located between Stations S4 and S6, with temperatures either side of the front being, on average, approximately $1{ }^{\circ} \mathrm{C}$ higher. By contrast, densities of $D$. acuta were more than ten times greater, with a peak abundance of 2840 cells/L at Station S7 near the mouth of Loch Fyne. There were no depth-related trends for either species but the highest densities of D. acuta were found in Stations S7 and S8 (Figure 7b), also coincident with the temperature front and on the seaward side. Abundance of D. acuta did not exceed 140 cells/L within Loch Fyne itself (Stations S1-S6). 

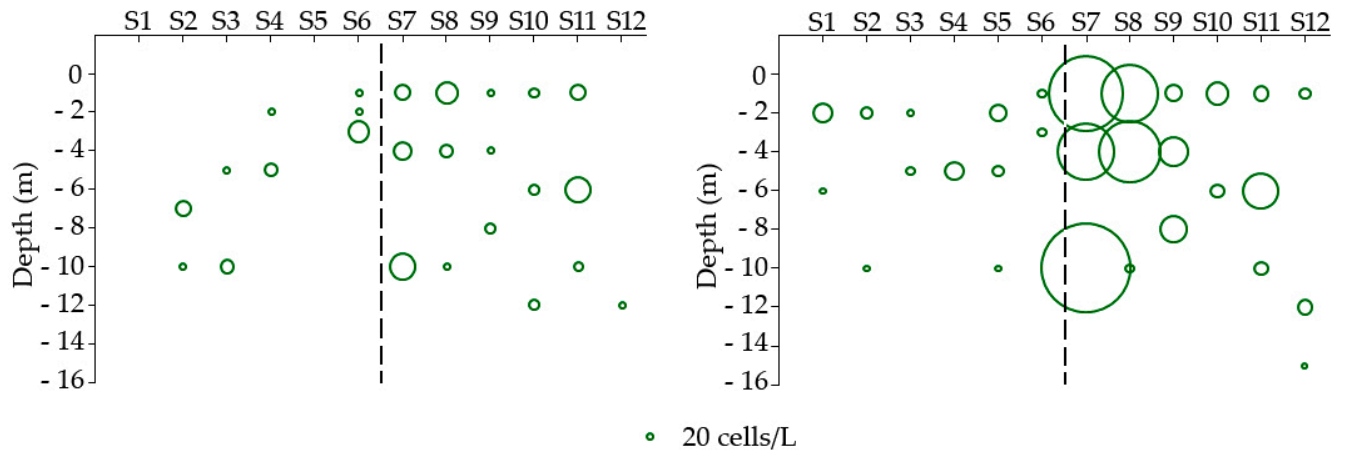

(a)

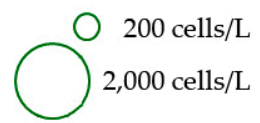

(b)

Figure 7. Abundance of (a) D. acuminata and (b) D. acuta in phytoplankton samples obtained from the research survey in early September. Stations S1 to S6 are in Loch Fyne and stations S7 to S12 are the more open waters of the Firth of Clyde (see Figure 1b). The temperature front between stations S6 and S7 is represented by a dashed line.

\subsubsection{Okadaic Acid Group Equivalent Toxicity and Toxin Concentration in Shellfish}

Figure 6 shows the variability in overall OA group toxicity in shellfish tissue collected from the regulatory monitoring sites around the Firth of Clyde between May and December 2015. The highest total toxin equivalent levels were recorded in mussels, with a value of $601 \mu \mathrm{g}$ OA eq. $/ \mathrm{kg}$ reported in samples collected from Campbeltown Loch (Site A) on 7 September, coinciding with the peak abundance of $D$. acuta recorded at this site. A value of $457 \mu \mathrm{g}$ OA eq. $/ \mathrm{kg}$ was reported, also in mussels, from Loch Fyne: Ardkinglas (Site C) a week after the dense bloom of 2980 cells/L of D. acuminata on 7 July. Okadaic acid group equivalent toxicity was lower in Pacific oysters and razor clams and the period of contamination was shorter, compared with that of the mussels. Two distinct OA group peaks were observed in Pacific oysters from Loch Fyne: Otter Ferry (Site D), the first peak of $69 \mu \mathrm{g}$ OA eq. $/ \mathrm{kg}$ coinciding with the $D$. acuminata bloom of 1080 cells/L on 9 June and the second peak of $77 \mu \mathrm{g}$ OA eq. $/ \mathrm{kg}$ on 1 September, following an increase in D. acuta in the preceding week. The maximum reported OA group equivalent toxin value in razor clams from Barassie (Site E) was much lower than in other shellfish species. Okadaic acid group toxicity at $17 \mu \mathrm{g} \mathrm{OA} \mathrm{eq.} / \mathrm{kg}$ was detected in a razor clam sample collected on 14 September, three weeks after a bloom of density 1980 cells/L that was composed of about $90 \%$ D. acuta. The earlier D. acuminata bloom at this site of 3540 cells/L recorded on 2 June did not appear to have any associated toxin contamination of shellfish. The detection of OA group toxins in mussels, including those from other biotoxin monitoring sites around the Firth of Clyde, continued for an extended period throughout autumn and into the winter months despite the absence of any causative organism by this time.

The proportion of each toxin analogue within the OA group changed over time for the three mussel sites A, B and C (Figure 8a). June mussel samples contained approximately $83 \%$ OA in both free and ester form, which decreased over time but was still present in December samples, contributing approximately $18 \%$ to the total OA group toxins by this time. Low levels of DTX1 were also recorded, with a maximum contribution of about $23 \%$ during May, declining to below the reporting limit by November. Concentrations of total OA and total DTX1 were detected at maximum values of $389 \mu \mathrm{g} / \mathrm{kg}$ and $85 \mu \mathrm{g} / \mathrm{kg}$, respectively from mussels collected at Loch Fyne: Ardkinglas in mid and late July 2015 (Figure 6). These elevated levels of OA and DTX1 appeared to follow the bloom of D. acuminata of density 2980 cells / L in early July. The DTX2 contribution increased from approximately $1 \%$ of the total OA group toxins in June to almost $82 \%$ by December (Figure $8 \mathrm{a}$ ). The highest recorded amount of DTX2 was $581 \mu \mathrm{g} / \mathrm{kg}$ (with Toxicity Equivalency Factor value of $349 \mu \mathrm{g} / \mathrm{kg}$ ), detected in mussels from Campbeltown Loch in late September 2015 (Figure 6). A greater proportion of the OA detected between May and July was in ester form (Figure 8b), with a ratio of 2:1 for esters:free but more 
similar proportions of free OA and OA esters were present in samples between August and October. Both DTX1 and DTX2 were detected mostly in free forms, except in May when DTX1 was all in ester form. Although low levels of pectenotoxins (PTXs) have previously been detected in mussels from Loch Fyne in 2009 during a bloom of predominantly D. acuminata [25], none were found in this study.

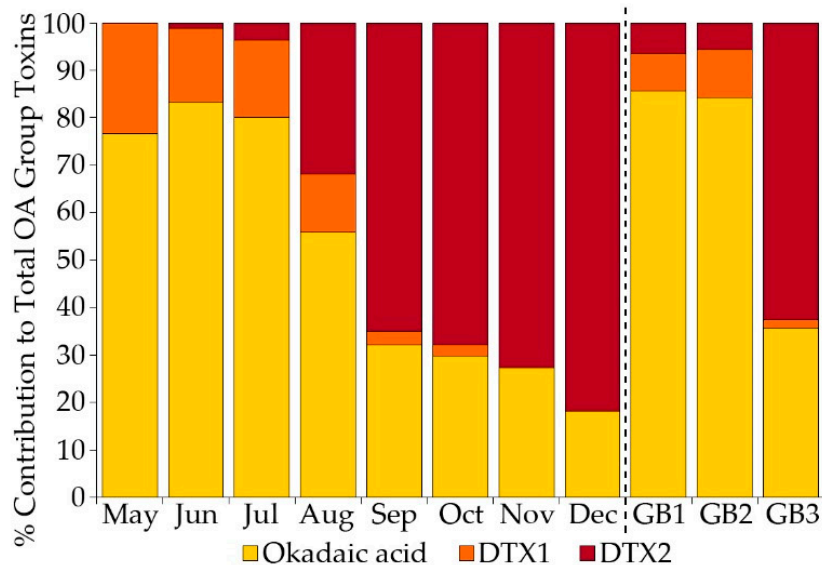

(a)
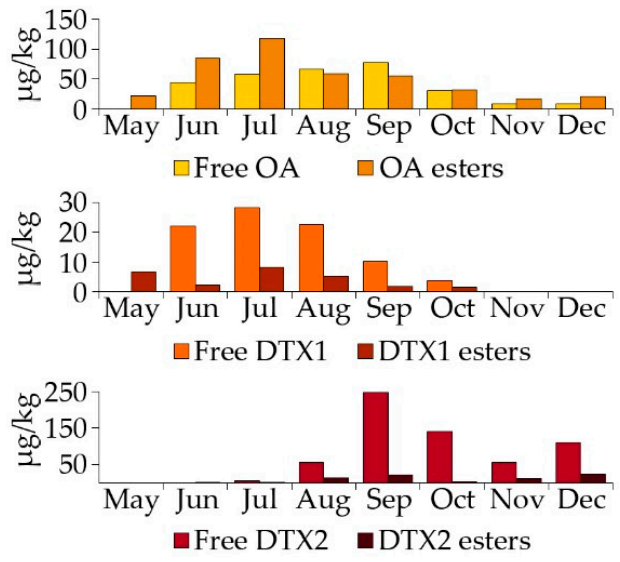

(b)

Figure 8. Mean percentage contribution of $\mathrm{OA}$ analogues and derivatives to total OA group toxins in mussels from sites A, B and C in the Firth of Clyde between May and December 2015 (a). For comparative purposes, the typical profiles obtained for mussels from Great Britain (GB1, GB2 and GB3) in the study by Johnson et al. [26] are also shown. (b) shows the proportion of free and esterified forms of each OA group toxin detected in the Firth of Clyde mussels.

\section{Discussion}

\subsection{Environmental Influences on Seasonality and Abundance of Dinophysis}

Both Dinophysis acuminata and D. acuta are regularly detected in the coastal waters of the North East Atlantic and the presence of these species, even at relatively low concentrations, results in a high incidence of shellfish contaminated with DSP toxins along the European Atlantic coast $[2,27,28]$. In Scottish coastal waters, maximum bloom densities of Dinophysis surveyed through the official control regulatory monitoring programme over the past 20 years have typically been in the region of 2000-10,000 cells/L, with infrequent observations of much denser patches, often in relatively enclosed areas. Dinophysis tends to be most abundant between May and September, prior to a late autumn decrease in line with the reduction in light levels associated with winter in temperate latitudes. The greatest Dinophysis cell densities in Scottish waters that usually occur between June and August are mainly composed of cells belonging to the D. acuminata complex. Dinophysis acuta blooms are observed less frequently than those of D. acuminata and tend to occur later in the year, typically from July onwards.

Our detailed analysis of the Clyde Sea sites and Loch Ewe conducted here concurs with the above qualitative assessment, indicating a dominance of D. acuminata in spring/summer with, in some years only, a switch to $D$. acuta dominance in late summer or autumn. Such temporal patterns have been observed elsewhere, for example along the Iberian shelf where the development of $D$. acuminata blooms usually begin in early March with the growth season extending until the autumnal transition from upwelling to downwelling [27-29]. In this region, D. acuta tends to occur in late summer-early autumn, although not every year, and has been associated with exceptionally hot summers [30] followed by a brief period of upwelling activity, leading to highly stratified conditions $[2,21,28,31]$. Blooms of $D$. acuta occurred between 1999 and 2002 in both Loch Ewe and around the Firth of Clyde with further occurrences in the Clyde and, to a lesser extent, Loch Ewe between 2014 and 2016. While the patterns 
of upwelling/downwelling that occur in Iberia are not a characteristic of Scottish waters, D. acuta blooms typically occur when seasonal stratification of the water column is likely [32,33].

Long-term variation in Dinophysis may be linked to climate [34,35]. Based on a modelling study, Gobler et al. [36] proposed that ocean warming had increased the growth rate and duration of the bloom season of D. acuminata over the period 1982-2006 in the North East Atlantic around the UK. However, following analysis of data from the Continuous Plankton Recorder (CPR) from the region, Dees et al. [37] did not find any increase in the number or annual duration of Dinophysis blooms. While the greatest number of $D$. acuminata above threshold counts occurred in each of the last three years (2015-2017), our results (Figures 2 and 5), albeit over a shorter timescale than that modelled by Gobler et al. [36], concur with the conclusion that there is no clear temporal increase in D. acuminata blooms. Our results for $D$. acuta also lead to a similar conclusion for this species.

In 2015 Dinophysis in the Firth of Clyde followed the typical pattern of an increase in D. acuminata through early summer, followed by a rise in the abundance of D. acuta in late summer and early autumn. Our boat-based field survey identified a pronounced temperature front between Stations S6 and S7 near the mouth of Loch Fyne. A substantial drop in nutrient concentrations across the front was also observed [24]. Fronts are known to be associated with dinoflagellate blooms [38-40] and in this case, we observed a separation of the phytoplankton community structure into distinct populations on either side of the front [24] with the largest concentrations of D. acuta at Stations S7 and S8 to the seaward side of the front (Figure 7), indicating that the front promoted the bloom or at least allowed wind-blown cells to accumulate against it. Such behaviour is consistent with the conceptual model of Smayda and Reynolds [41], who suggest that Dinophysis spp. are a transitional life form along the onshore-offshore mixing nutrient gradient, seeming to prefer areas of less pronounced turbulence. While they tolerate coastal upwelling sites and form modest blooms during periods of upwelling relaxation, they are common in areas where there is greater seasonal stratification and lower nutrients. Given that $D$. acuta blooms occurred in the same years in the geographically distinct Clyde Sea and Loch Ewe, local processes do not appear to control the bloom/non-bloom dynamics of this species but are likely to govern the specific location of events and their magnitude. Similar behaviour has also been reported from Irish waters with Raine et al. [42] noting that D. acuta mainly occurred in stratified shelf waters in late summer and hypothesizing that $D$. acuta populations developed rapidly close to tidal fronts where productivity is high. It is important to note that $D$. acuminata, although present during our 2015 survey, did not bloom nor aggregate near the frontal region, confirming the species-specific response to environmental forcing of the genus.

Other oceanographic conditions are also thought to be important in influencing Dinophysis transport and bloom formation. For example, coastal jets have been linked to movement of Dinophysis around the south-west of Ireland [40,43], with blooms being advected into coastal embayments through wind-driven exchange of water masses [40]. Such advection may result in large toxic blooms through physical accumulation rather than in situ growth $[10,44]$. Particle tracking model simulations by Paterson et al. [24] suggested that D. acuta was advectively transported into the Clyde Sea from the open sea of the North Channel. The model also predicted significant interannual differences in advection are likely in the area, with the potential for cells to be more readily exchanged between the outer waters of the Firth of Clyde and the enclosed waters of Loch Fyne (where aquaculture is concentrated) in the absence of a front.

\subsection{Dinophysis and Toxin Profiles}

Our results demonstrate that transition from a D. acuminata to a D. acuta dominated community in both the Clyde and Loch Ewe occurred on a number of occasions and influenced OA group toxicity detected in a range of bivalve shellfish species collected during the bloom periods. The relationship between Dinophysis abundance and accumulation of OA group toxins in shellfish can vary considerably and there are many factors that will determine the amount of toxin ingested by the shellfish and the rate of toxin depuration. These include the availability of other non-toxic phytoplankton species 
for filter feeding [45], the ingestion of other potentially toxic vector species and the location of the bivalve in the water column, whether suspended from a raft or occupying the intertidal zone [46]. Bivalve contamination will also depend on the response of the shellfish to a specific phytoplankton species or toxin $[47,48]$ and the toxic potential of individual cells ingested, which may vary temporally, geographically and in response to life stage and nutrient availability $[2,49,50]$. Toxin content can vary within the same species collected from the same location at different times $[51,52]$ and even between cells of a single species within a daily cycle [51]. Different shellfish species are also known to metabolize diarrhetic shellfish toxins differently $[4,53]$ and mussels have been found to accumulate higher levels of diarrhetic shellfish toxins than other species when exposed to the same algal bloom conditions [4,53-58]. Consistent with this, the rope-grown mussels obtained from the Firth of Clyde in 2015 showed the highest level of OA group contamination. However, toxins in both Pacific oysters and razor clams remained below the MPL throughout the Dinophysis bloom period.

Dinophysis has a worldwide distribution but separate species have been associated with the production of different analogues of the OA group toxins, depending on geographic locality. The relative timing and size of D. acuminata and D. acuta blooms is therefore of considerable significance to the toxic contamination of shellfish that will likely result. Pectenotoxins have been identified as a dominant component of the toxin profile in D. acuminata from New Zealand [59], Japan [60,61], Chile [62,63], Argentina [64] and North America [49,63], with smaller amounts of OA and DTX1 also present. In European waters, D. acuminata is more associated with the production of OA. Okadaic acid has been linked to D. acuminata on the Swedish west coast [65] and in Denmark only OA and OA esters were identified in blue mussels during a bloom of D. acuminata [66]. However, a further study on Danish isolates showed strains of D. acuminata to produce only PTX2 and no OA or DTX [67]. Further south, OA was identified in D. acuminata samples collected in 1998 from north-west Spain and cells obtained in September were found to have an OA concentration of more than double that of June cells [68]. Blooms of D. acuminata in Portugal have also been associated with OA [69], as was a bloom in the Bay of Seine (northern France) [70]. Our study is consistent with the geographical patterns described above in demonstrating that $D$. acuminata blooms in Scottish coastal waters are associated with toxin profiles in shellfish dominated by OA, with a smaller contribution from DTX1.

Pectenotoxins also dominated the toxin profile of D. acuta from New Zealand waters [59], with a small amount of OA found but no DTX2. By contrast, various studies from around Spain, Portugal and Ireland have associated the presence of D. acuta with DTX2. Both OA and DTX2 at an approximate ratio of 3:2 were found in D. acuta collected from north-west Spain in 1997 [68] and DTX2, OA and PTX2 were also present in isolates of $D$. acuta from the same area in 2005-6, with a fairly constant ratio of 3:2 for OA:DTX2 [51] but with variations in toxin cell quota in different months [51]. Increased levels of DTX2 in Portuguese shellfish during late summer and early autumn of 1994 and 1995 also were associated with blooms of D. acuta [69]. Both DTX2 and OA in varying proportions were found in D. acuta obtained from the Celtic Sea and the south coast of Ireland [71,72]. A further study in the same area reported that D. acuta related concentrations of DTX2 and PTX2 were greater than OA in all the samples analysed [73]. Further north, during a bloom of predominantly D. acuta off the north-east coast of England in September 2002, mussels were found to contain 76\% DTX2, 15\% OA and 9\% PTX2 [74]. Johnson et al. [26] also identified a toxin profile for mussels collected around Great Britain between 2011 and 2015 that contained DTX2 at 63\%, with OA at $35 \%$ and a small amount of DTX1 $(<2 \%)$.

Our investigation of the Firth of Clyde 2015 event showed that the proportion of toxins contributing to the OA group varied throughout the year, with more OA and DTX1 detected in shellfish between May and August followed by an increase in DTX2, such that it was the dominant toxin by early September. The increase in the abundance of $D$. acuta and its replacement of $D$. acuminata as the dominant species contributed to a greater proportion of DTX2 contamination of shellfish in both the Clyde in 2015 and Loch Ewe in 2001 and 2002. Some studies have hypothesized that blooms of D. acuta may result in extended periods of toxic contamination of shellfish. Vale, 2004 [54], examined 
the elimination rates of OA and DTX2 in both mussels and oysters and concluded that DTX2 was eliminated at a slower rate than OA in mussels, although the elimination rate of DTX2 in cockles was similar to that of OA. Mussels from Loch Ewe (this study) remained contaminated with both DTX2 and OA into the winter of 2001, although only DTX2 was still present in mussels during winter 2002. In the Clyde mussel samples, the proportion of free OA to esterified OA increased throughout the summer months and DTX2 was predominantly present in non-esterified form. Our study revealed a prolonged period of toxic contamination of shellfish in the absence of any causative organism, due to the continuing presence of DTX2 and, to a lesser extent, OA in mussel and oyster samples through the autumn and winter of 2015 in the Firth of Clyde. These results support the hypothesis proposed by Vale, 2006 [55], that esterified forms of OA and DTX2 in mussels and clams are eliminated more rapidly than free OA and DTX2 but that DTX2 is less esterified than OA in these species, leading to a build-up of free DTX2.

Johnson et al. [26] examined the OA group toxin profiles in 98 samples of mussels obtained from around Great Britain between 2011 and 2015 as part of the official control monitoring programme. They identified three different toxin profiles, the first (GB1 in Figure 8a) being dominated by OA in both free and ester form (about $86 \%$ ), with a small amount of DTX1 (8\%) and very little DTX2 $(6 \%)$. The second profile (GB2) was also dominated by OA but with a higher proportion of OA in ester form, approximately $59 \%$ compared to $36 \%$ in GB1. The third profile (GB3) contained a much larger proportion of DTX2 (about $63 \%$ ) present, mostly as free DTX2 (mean 58\%). Pectenotoxins were absent in all the mussel samples tested. Similarly, in an analysis of toxin profiles from various shellfish species obtained around the coast of Scotland, England and Wales between 2011 and 2016, Dhanji-Rapkova et al. [16] identified three distinct profiles, with Profile 1 being dominated by OA $(87 \%)$, Profile 2 more of a mix between OA (45\%) and DTX2 (52\%) and Profile 3 mostly composed of DTX2 (85\%). A comparison between the toxin profiles in mussels determined from the Johnson et al. [26] investigation and the results obtained in the Firth of Clyde 2015 study (Figure 8) showed that the toxin profiles obtained for mussels in June and July were very similar to the profile for GB2. Okadaic acid contributed $>80 \%$ to the total toxin content, with approximately twice as much OA in ester form compared with free OA. However, the September and October toxin profiles showed a much greater similarity with the profile for GB3 where DTX2 in both free and ester form contributed $>63 \%$ to the total toxic potential.

Food business operators are required through regulation to ensure that unsafe products are not placed on the market and a number of relatively simple, rapid and inexpensive kits are commercially available that are used by the shellfish industry to test for the presence of DSTs in harvested shellfish. These use a variety of methods including quantitative enzyme linked immunosorbent assays, protein phosphatase inhibition assays and qualitative lateral flow immunoassays. The investigation by Johnson et al. [26] examined four of these rapid test kits to compare their performance with the results obtained by the official control method (LC-MS/MS) for a threshold of $80 \mu \mathrm{g} \mathrm{OA} \mathrm{eq.} / \mathrm{kg}$, which is half the MPL of OA group equivalent toxicity allowed in shellfish tissue. The authors found good agreement in the results for both toxin profiles GB1 and GB2, recorded as either positive or negative for the $0.5 \mathrm{MPL}$ threshold but there was a larger proportion of false negatives for profile GB3 with the majority of the rapid test kits. Generally, the results from the rapid test kits gave a reliable indication of OA group toxin contamination in the mussels but performance was less accurate when there was a larger proportion of DTX2 present.

\section{Conclusions}

Our results confirm that the species diversity within Dinophysis populations in Scottish waters can vary interannually. Dinophysis acuminata is predominant in Scottish coastal waters and its presence is associated with contamination of shellfish with OA and DTX1, although occasional blooms of $D$. acuta can lead to prolonged contamination with DTX2. In some shellfish production areas, there is often a limited "window of opportunity" for harvesting between site closures due to spring/early 
summer contamination with paralytic shellfish toxins and those caused by diarrhetic shellfish toxins in mid/late summer. The decision to harvest may be based on a negative result returned by a rapid test kit if the tissue sample contains a high proportion of DTX2, although the regulatory LC-MS/MS test could return a positive result for a similar sample. This can result in expensive product recalls and the associated loss of consumer confidence for all shellfish products. Routine enumeration of Dinophysis to species level could provide early warning of potential contamination of shellfish with DTX2 and thus determine the choice of the most suitable kit for effective end-product testing. This would provide better protection to the health of consumers and reduce the potential impact to the shellfish aquaculture industry.

\section{Materials and Methods}

\subsection{Study Areas}

The two study sites are both located on the west coast of Scotland, an area characterised by islands and fjordic sea lochs that provide a sheltered location for much of Scotland's aquaculture industry. Loch Ewe is a fjordic sea loch on the Scottish west coast (Figure 1a), approximately $12 \mathrm{~km}$ long, with a mean depth of around $21 \mathrm{~m}$ and a maximum depth of $73 \mathrm{~m}$ [75]. It has only a slightly discernible sill at $33 \mathrm{~m}$ depth, resulting in it being associated with the more open waters of the North Minch [76,77]. Loch Ewe is part of the Scottish Coastal Observatory (SCObs) operated by Marine Science Scotland (MSS) where multiple physical, chemical and biological parameters are collected on a weekly basis [78]. Further south, the Firth of Clyde is a large fjordic basin with a number of associated sea lochs. It opens into the North Channel of the Irish Sea [79]. The regulatory monitoring points in this region were located on the southern end of the Kintyre peninsula, on the eastern side of the Firth of Clyde near Ayr and further north in Loch Striven and Loch Fyne (indicated by A-E in Figure 1b).

\subsection{Phytoplankton Samples}

Seawater samples were collected from classified shellfish production areas, the sampling method being either a PVC sampling tube or a bucket, depending on the depth of water at each site. The sampling tube allows for the collection of a depth-integrated water sample from 0-10 m. A well-mixed $500 \mathrm{~mL}$ (SAMS) or $1 \mathrm{~L}$ (MSS) sub-sample of this water was fixed on site, to obtain a final concentration of approximately 1\% (SAMS) or $0.5 \%$ (MSS) acidic Lugol's iodine and then returned to the laboratory for analysis. The phytoplankton in a $50 \mathrm{~mL}$ sub-sample (detection limit 20 cells /L) was allowed to settle onto the base plate of a chamber for a minimum of $20 \mathrm{~h}$ before analysis, following the method described by Utermöhl, 1958 [80]. Cells belonging to the order Dinophysiales were identified and enumerated using inverted light microscopy and subsequent re-analysis of samples allowed assignation of cells to species level where this had not been recorded during the original routine analysis for the regulatory monitoring programme. Phytoplankton data collected through regulatory monitoring by both MSS (1996 to June 2005) and SAMS (September 2005 onwards) were examined to determine the prevalence and seasonality of D. acuminata and D. acuta in the Firth of Clyde and the long-term MSS SCObs site in Loch Ewe.

Supplementary phytoplankton data were also available from a research cruise that was conducted between 8-9 September 2015 aboard RV Seòl Mara [24], with sampling taking place at stations around the Clyde Sea and in Loch Fyne (Figure 1b). Oxygen, temperature, salinity and fluorescence were recorded by CTD (SBE 19, Seabird Electronics) and water samples were collected by Niskin bottle into $500 \mathrm{~mL}$ opaque plastic bottles and preserved with acidic Lugol's iodine. Three depths were sampled at each station corresponding to surface, chlorophyll maximum and below the chlorophyll maximum, guided by CTD in-situ fluorescence data. Samples were analysed for the presence of phytoplankton following the Utermöhl method. 


\subsection{Shellfish Samples}

Shellfish species collected from around the Firth of Clyde consisted of common mussels (Mytilus edulis), Pacific oysters (Magallana gigas) and razor clams (Ensis spp.) (Table 1). Samples were collected, packaged and transported to the Centre for Environment, Fisheries and Aquaculture Science (Cefas) within validated temperature-controlled containers, in accordance with Cefas guidance and protocols. Enough shellfish, with a minimum of ten organisms per sample, were taken to provide a sample characteristic of the Representative Monitoring Point (RMP) and a minimum weight of $100 \mathrm{~g}$ tissue once the shellfish were shucked.

Table 1. Number of phytoplankton and shellfish samples collected from around the Firth of Clyde between May and December 2015 and used in this study. The number of tissue samples containing total OA group equivalent toxicity exceeding the Maximum Permitted Level (MPL) of $160 \mu \mathrm{g}$ OA eq. $/ \mathrm{kg}$ is also shown.

\begin{tabular}{lcccc}
\hline \multicolumn{1}{c}{ Site } & Shellfish Species & $\begin{array}{c}\text { Phytoplankton } \\
\text { Samples }\end{array}$ & $\begin{array}{c}\text { Tissue } \\
\text { Samples }\end{array}$ & $\begin{array}{c}\text { OA group Equiv. } \\
\text { Toxicity > MPL }\end{array}$ \\
\hline (A) Campbeltown Loch & Common mussels & 16 & 28 & 15 \\
(B) Loch Striven & Common mussels & 6 & 22 & 9 \\
(C) Loch Fyne: Ardkinglas & Common mussels & 19 & 29 & 9 \\
(D) Loch Fyne: Otter Ferry & Pacific oysters & 19 & 31 & 0 \\
(E) Barassie & Razor clams & 19 & 20 & 0 \\
\hline
\end{tabular}

Okadaic acid group toxins present in shellfish tissue were determined using a method validated at Cefas [81] based on that described by the EU Reference Method for lipophilic toxins, using liquid chromatography tandem mass spectrometry (LC-MS/MS). This method has been used for official control monitoring in the UK including Scotland since July 2011 [16]. Aliquots of $2.0 \pm 0.01 \mathrm{~g}$ shellfish tissue from each sample were subjected to a double extraction each using $9 \mathrm{~mL}$ of methanol. Post-centrifugation, $0.2 \mu \mathrm{m}$ filtered supernatants were subjected to both direct LC-MS/MS analysis and an alkaline hydrolysis step to liberate the esterified OA group toxins [82]. Two Waters, Acquity and Acquity I-class, (Waters Ltd., Manchester, UK) Ultra Performance Liquid Chromatographic (UPLC) systems were coupled to Waters Xevo TQ and Xevo TQ-S MS/MS systems respectively. A high pH LC method described by Gerssen et al. [14] was adopted with modifications [81]. Mobile phase A was prepared from $2 \mathrm{mM}$ ammonium bicarbonate adjusted to $\mathrm{pH} 11 \pm 0.2$ with ammonium hydroxide. Mobile phase B was $2 \mathrm{mM}$ ammonium bicarbonate in 90\% acetonitrile, also adjusted to $\mathrm{pH} 11 \pm 0.2$ with ammonium hydroxide. On both systems, a Waters BEH C18 reverse phase UPLC column $(2.1 \times 50 \mathrm{~mm}, 1.7 \mu \mathrm{m})$ was used in series with a pre-column VanGuard cartridge. The mobile phase flow rate was held at $0.6 \mathrm{~mL} / \mathrm{min}$, with column temperatures, run times and injection volumes optimised for the two instruments independently. MS/MS parameters used were those given by Turner and Goya, 2015 [83].

Toxins in shellfish extracts were quantified against calibration solutions prepared from Certified Reference Material (CRM) standards obtained from the Institute of Biotoxin Metrology, National Research Council of Canada (NRCC). Chromatographic retention times together with two Selected Reaction Monitoring (SRM) transitions, optimised for each toxin, were utilised for qualitative identification of toxins, with the primary SRM used for quantitative purposes. Hydrolysed extracts were analysed alongside the unhydrolysed filtrates to enable the quantitation of both free OA group toxins (OA, DTX1 and DTX2) and OA group esters (DTX3s) [82]. Within the regulatory monitoring programme, results are reported as total $\mu \mathrm{g}$ OA equivalent $/ \mathrm{kg}$, with a Toxicity Equivalency Factor of 0.6 used for DTX2 [9]. Measurement uncertainty, determined for each shellfish species/toxin analogue combination, is then applied to each quantifiable toxin concentration and used to calculate an overall uncertainty for each total toxic potential estimation. As a precautionary measure, the higher value is used to determine whether the total OA equivalent $/ \mathrm{kg}$ exceeds the MPL, although actual total OA equivalent $/ \mathrm{kg}$ values are reported in this study. Okadaic acid group toxin values reported 
in excess of $400 \mu \mathrm{g}$ OA eq. $/ \mathrm{kg}$ should be regarded as estimations, as such levels fall outside the operationally-defined linear working range of the instrument.

Additional MSS data on OA group toxins in common mussels were also available for Loch Ewe between 2001 and 2002 [13]. The concentrations of okadaic acid, DTX1 and DTX2 in 80\% $(v / v)$ aqueous methanol shellfish extracts were determined using an API 150EX single quadrupole mass spectrometer, equipped with a Turbolonspray source (Applied Biosystems, Warrington, UK). This was coupled to an Agilent 1100 series HPLC system (Agilent Technologies, West Lothian, UK) comprising of a de-gasser, quaternary pump and autosampler. A reversed-phase column was used for the analysis (Thermo Hypersil $C_{8}$ BDS, $50 \times 2.1 \mathrm{~mm}$, particle size $3 \mu \mathrm{m}$ ) with a $10 \mathrm{~mm}$ guard cartridge of the same stationary phase. The isocratic mobile phase consisted of $2 \mathrm{mM}$ ammonium formate with $50 \mathrm{mM}$ formic acid in $50 \%(v / v)$ acetonitrile. The flow rate and run time for both analyses were $0.25 \mathrm{~mL} / \mathrm{min}$ and $10 \mathrm{~min}$ respectively. An aliquot of $5 \mu \mathrm{L}$ was injected onto the analytical column. The mobile phase was directly infused into the mass spectrometer after $1.5 \mathrm{~min}$ and the initial mobile phase was put to waste using a switching valve.

Author Contributions: Conceptualization by S.C.S., A.D.T., K.D. and C.W.; S.C.S. and E.B. identified the Dinophysis from the regulatory monitoring samples and E.B. supplied information from the SCObs; Toxin data were collected by A.D.T. and E.B.; R.F.P. and S.M. conducted the Clyde field study and R.F.P., S.M. and E.M. performed sample and data analyses; The original draft was prepared by S.C.S., A.D.T., E.B., C.W., R.F.P. and K.D.; Review \& editing was performed by S.C.S., A.D.T., E.B. and K.D.; S.C.S. prepared the figures and final version.

Funding: The laboratory analyses for biotoxins in shellfish were conducted by the Centre for Environment, Fisheries and Aquaculture Science (Cefas) Weymouth Laboratory, whilst the laboratory phytoplankton analyses were performed by the Scottish Association for Marine Science (SAMS) in Oban during 2015. The programmes were aimed at delivering the testing required for the statutory monitoring of biotoxins in shellfish and for identification and enumeration of potentially harmful algal species in selected shellfish harvesting areas, as described in EC Regulations 854/2004, 882/2004 and 2074/2005. They were funded by and delivered on behalf of, Food Standards Scotland (FSS), the national competent authority for food safety. Marine Science Scotland (MSS) phytoplankton data was collected as part of the SOAEFD and Food Standards Agency, UK Toxic Phytoplankton Monitoring Programme in Scotland and the Scottish Coastal Observatory (ST05a). Toxin analysis from 2001-2003 was performed under the Food Standards Agency, Scotland project B04008. The boat based field survey was funded by the BBSRC/NERC ShellEye project [grant reference NE/P011004/1]. R.F.P. was supported by a PhD studentship co-funded by FSS and SAMS, and K.D. was funded by BBSRC/NERC grant BB/M025934/1 and the NWE Europe Interreg project PRIMROSE.

Acknowledgments: All official control samples analysed and used to provide the data for this study were acquired and tested as part of the Food Standards Scotland funded regulatory marine biotoxin monitoring programme.

Conflicts of Interest: The authors declare no conflict of interest.

\section{References and Notes}

1. Davidson, K.; Bresnan, E. Shellfish toxicity in UK waters: A threat to human health? Environ. Health 2009, 8, S12. [CrossRef] [PubMed]

2. Reguera, B.; Riobó, P.; Rodríguez, F.; Díaz, P.A.; Pizarro, G.; Paz, B.; Franco, J.M.; Blanco, J. Dinophysis Toxins: Causative organisms, distribution and fate in shellfish. Mar. Drugs 2014, 12, 394-461. [CrossRef] [PubMed]

3. Smayda, T.J. Harmful Algal Bloom Communities in Scottish Coastal Waters: Relationship to Fish Farming and Regional Comparisons-A Review. 2006. Available online: http:/ /www.gov.scot/Publications/2006/ 02/03095327/0 (accessed on 3 February 2006).

4. Trainer, V.L.; Moore, L.; Bill, B.D.; Adams, N.G.; Harrington, N.; Borchert, J.; da Silva, D.A.M.; Eberhart, B.-T.L. Diarrhetic shellfish toxins and other lipophilic toxins of human health concern in Washington State. Mar. Drugs 2013, 11, 1815-1835. [CrossRef] [PubMed]

5. Scoging, A.; Bahl, M. Diarrhetic shellfish poisoning in the UK. Lancet 1998, 352, 117. [CrossRef]

6. Whittle, K.; Gallacher, S. Marine toxins. Br. Med. Bull. 2000, 56, 236-253. [CrossRef] [PubMed]

7. Hinder, S.L.; Hays, G.C.; Brooks, C.J.; Davies, A.P.; Edwards, M.; Walne, A.W.; Gravenor, M.B. Toxic marine microalgae and shellfish poisoning in the British Isles: History, review of epidemiology and future implications. Environ. Health 2011, 10. [CrossRef] [PubMed]

8. McDougall, S.; Midgley, P. The Scottish live bivalve mollusc monitoring programme and Enforcement. Scottish food advisory committee report 2010. FSAS 11/08/01 19 pp. 
9. European food safety Authority. Opinion of the Scientific Panel on Contaminants in the Food chain on a request from the European Commission on marine biotoxins in shellfish-Okadaic acid and analogues. EFSA J. 2008, 589, 1-62.

10. Whyte, C.; Swan, S.; Davidson, K. Changing wind patterns linked to unusually high Dinophysis blooms around the Shetland Islands, Scotland. Harmful Algae 2014, 39, 365-373. [CrossRef]

11. European Commission. Regulation (EC) No. 854/2004 of the European Parliament and of the Council of 29 April 2004 laying down specific rules for the organisation of official controls on products of animal origin intended for human consumption. Off. J. Eur. Union 2004, Annex II, Chapter II, B, 1c and 4a.

12. Managing Shellfish Toxin Risks: Guidance For Harvesters and Processors. Available online: http:/ / www.foodstandards.gov.scot/publications-and-research/managing-shellfish-toxin-risks-forharvesters-and-processors (accessed on 30 May 2018).

13. Bresnan, E.; Fryer, R.; Hart, M.; Percy, L. Correlation between algal presence in water and toxin presence in shellfish. Fish. Res. Serv. Contract Rep. 2005, 4, 5-27.

14. Gerssen, A.; Mulder, P.P.J.; McElhinney, M.A.; de Boer, J. Liquid chromatography-tandem mass spectrometry for the detection of marine lipophilic toxins under alkaline conditions. J. Chromatogr. A. 2009, 1216, 1421-1430. [CrossRef] [PubMed]

15. Stobo, L.A.; Lacaze, J.-P.C.L.; Scott, A.C.; Petrie, J.; Turrell, E.A. Surveillance of algal toxins in shellfish from Scottish waters. Toxicon 2008, 51, 635-648. [CrossRef] [PubMed]

16. Dhanji-Rapkova, M.; O’Neill, A.; Maskrey, B.H.; Coates, L.; Teixeira Alves, M.; Kelly, R.J.; Hatfield, R.G.; Rowland-Pilgrim, S.J.; Lewis, A.M.; Algoet, M.; et al. Variability and profiles of lipophilic toxins in bivalves from Great Britain during five and a half years of monitoring: Okadaic acid, dinophysis toxins and pectenotoxins. Harmful Algae 2018, 77, 66-80. [CrossRef] [PubMed]

17. Edvardsen, B.; Shalchian-Tabrizi, K.; Jakobsen, K.S.; Medlin, L.K.; Dahl, E.; Brubak, S.; Paasche, E. Genetic variability and molecular phylogeny of Dinophysis species (Dinophyceae) from Norwegian waters inferred from single cell analysis of rDNA. J. Phycol. 2003, 39, 395-408. [CrossRef]

18. Stern, R.F.; Amorim, A.L.; Bresnan, E. Diversity and plastid types in Dinophysis acuminata complex (Dinophyceae) in Scottish waters. Harmful Algae 2014, 39, 223-231. [CrossRef]

19. Reguera, B.; Velo-Suárez, L.; Raine, R.; Park, M.G. Harmful Dinophysis species: A review. Harmful Algae 2012, 14, 87-106. [CrossRef]

20. Reguera, B.; González-Gil, S. Small cell and intermediate cell formation in species of Dinophysis (Dinophyceae, Dinophysiales). J. Phycol. 2001, 37, 318-333. [CrossRef]

21. Moita, M.T.; Sobrinho-Gonçalves, L.; Oliveira, P.B.; Palma, S.; Falcão, M. A bloom of Dinophysis acuta in a thin layer off North-West Portugal. Afr. J. Mar. Sci. 2006, 28, 265-269. [CrossRef]

22. González-Gil, S.; Pizarro, G.; Paz, B.; Velo-Suárez, L.; Reguera, B. Considerations on the toxigenic nature and prey sources of Phalacroma rotundatum. Aquat. Microb. Ecol. 2011, 64, 197-203. [CrossRef]

23. Foden, J.; Purdie, D.A.; Morris, S.; Nascimento, S. Epiphytic abundance and toxicity of Prorocentrum lima populations in the Fleet Lagoon, UK. Harmful Algae 2005, 4, 1063-1074. [CrossRef]

24. Paterson, R.F.; McNeill, S.; Mitchell, E.; Adams, T.; Swan, S.C.; Clarke, D.; Miller, P.I.; Bresnan, E.; Davidson, K. Environmental control of harmful dinoflagellates and diatoms in a fjordic system. Harmful Algae 2017, 69, 1-17. [CrossRef] [PubMed]

25. Morris, S.; Stubbs, B.; Brunet, C.; Davidson, K. Spatial distributions and temporal profiles of harmful phytoplankton and lipophilic toxins in Common mussels and Pacific oysters from four Scottish shellfish production areas (2009). Final project report to the Food Standards Agency in Scotland, 2010; p. 57.

26. Johnson, S.; Harrison, K.; Turner, A.D. Application of rapid test kits for the determination of Diarrhetic Shellfish Poisoning (DSP) toxins in bivalve molluscs from Great Britain. Toxicon 2016, 111, 121-129. [CrossRef] [PubMed]

27. Escalera, L.; Pazos, Y.; Doval, M.D.; Reguera, B. A comparison of integrated and discrete depth sampling for monitoring toxic species of Dinophysis. Mar. Pollut. Bull. 2012, 64, 106-113. [CrossRef] [PubMed]

28. Moita, M.T.; Pazos, Y.; Rocha, C.; Nolasco, R.; Oliveira, P.B. Toward predicting Dinophysis blooms off NW Iberia: A decade of events. Harmful Algae 2016, 53, 17-32. [CrossRef] [PubMed]

29. Díaz, P.A.; Reguera, B.; Ruiz-Villarreal, M.; Pazos, Y.; Velo-Suárez, L.; Berger, H.; Sourisseau, M. Climate variability and oceanographic settings associated with interannual variability in the initiation of Dinophysis acuminata blooms. Mar. Drugs 2013, 11, 2964-2981. [CrossRef] [PubMed] 
30. Escalera, L.; Reguera, B.; Pazos, Y.; Moroño, A.; Cabanas, J.M. Are different species of Dinophysis selected by climatological conditions? Afr. J. Mar. Sci. 2006, 28, 283-288. [CrossRef]

31. Díaz, P.A.; Ruiz-Villarreal, M.; Pazos, Y.; Moita, T.; Reguera, B. Climate variability and Dinophysis acuta blooms in an upwelling system. Harmful Algae 2016, 53, 145-159. [CrossRef] [PubMed]

32. Jones, K.J.; Gowen, R.J. Influence of stratification and irradiance regime on summer phytoplankton composition in coastal and shelf seas of the British Isles. Estuarine Coast. Shelf Sci. 1990, 30, 557-567. [CrossRef]

33. Midgley, R.P.; Simpson, J.H.; Hyder, P.; Rippeth, T.P. Seasonal cycle of vertical structure and deep waters renewal in the Clyde Sea. Estuarine Coast. Shelf Sci. 2001, 53, 813-823. [CrossRef]

34. Edwards, M.; Johns, D.G.; Leterme, S.C.; Svendsen, E.; Richardson, A.J. Regional climate change and harmful algal blooms in the northeast Atlantic. Limnol. Oceanogr. 2006, 51, 820-829. [CrossRef]

35. Naustvoll, L.J.; Gustad, E.; Dahl, E. Monitoring of Dinophysis species and diarrhetic shellfish toxins in Flødevigen Bay, Norway: Inter-annual variability over a 25-year time-series. Food Addit. Contam. Part A 2012, 29, 1605-1615. [CrossRef] [PubMed]

36. Gobler, C.J.; Doherty, O.M.; Hattenrath-Lehmann, T.K.; Griffith, A.W.; Kang, Y.; Litaker, R.W. Ocean warming since 1982 has expanded the niche of toxic algal blooms in the North Atlantic and North Pacific oceans. Proc. Natl. Acad. Sci. USA 2017, 114, 4975-4980. [CrossRef] [PubMed]

37. Dees, P.; Bresnan, E.; Dale, A.C.; Edwards, M.; Johns, D.; Mouat, B.; Whyte, C.; Davidson, K. Harmful algal blooms in the Eastern North Atlantic ocean. Proc. Natl. Acad. Sci. USA 2017, 114, 124-126. [CrossRef] [PubMed]

38. Franks, P.J.S. Sink or swim: Accumulation of biomass at fronts. Mar. Ecol. Prog. Ser. 1992, 82, 1-12. [CrossRef]

39. Franks, P.J.S. Phytoplankton blooms at fronts: Patterns, scales and physical forcing. Rev. Aquat. Sci. 1992, 6, 121-137.

40. Raine, R. A review of the biophysical interactions relevant to the promotion of HABs in stratified systems: The case study of Ireland. Deep Sea Res. Part II Top. Stud. Oceanogr. 2014, 101, 21-31. [CrossRef]

41. Smayda, T.J.; Reynolds, C.S. Community Assembly in Marine Phytoplankton: Application of Recent Models to Harmful Dinoflagellate Blooms. J. Plankton Res. 2001, 23, 447-461. [CrossRef]

42. Raine, R.; Cosgrove, S.; Fennell, S.; Gregory, C.; Barnett, M.; Purdie, D.; Cave, R. Origins of Dinophysis blooms which impact Irish aquaculture. In Marine and Freshwater Harmful Algae, Proceedings of the 17th International Conference on Harmful Algae, Florianópolis, Brazil, 9-14 October 2016; Proença, L.A.O., Hallegraeff, G.M., Eds.; International Society for the Study of Harmful Algae: Paris, France, 2017; pp. 46-49.

43. Farrell, H.; Gentien, P.; Fernand, L.; Lunven, M.; Reguera, B.; González-Gil, S.; Raine, R. Scales characterising a high density thin layer of Dinophysis acuta Ehrenberg and its transport within a coastal jet. Harmful Algae 2012, 15, 36-46. [CrossRef]

44. Davidson, K.; Anderson, D.M.; Mateus, M.; Reguera, B.; Silke, J.; Sourisseau, M.; Maguire, J. Forecasting the risk of harmful algal blooms: Preface to the Asimuth special issue. Harmful Algae 2016, 53, 1-7. [CrossRef] [PubMed]

45. Svensson, S. Depuration of Okadaic acid (diarrhetic shellfish toxin) in mussels, Mytilus edulis (Linnaeus), feeding on different quantities of nontoxic algae. Aquaculture 2003, 218, 277-291. [CrossRef]

46. Bricelj, V.M.; Shumway, S.E. Paralytic shellfish toxins in bivalve molluscs: Occurrence, transfer kinetics and biotransformation. Rev. Fish. Sci. 1998, 6, 315-383. [CrossRef]

47. Sidari, L.; Nichetto, P.; Cok, S.; Sosa, S.; Tubaro, A.; Honsell, G.; Della Loggia, R. Phytoplankton selection by mussels and diarrhetic shellfish poisoning. Mar. Biol. 1998, 131, 103-111. [CrossRef]

48. Nielsen, L.T.; Hansen, P.J.; Krock, B.; Vismann, B. Accumulation, transformation and breakdown of DSP toxins from the toxic dinoflagellate Dinophysis acuta in blue mussels, Mytilus edulis. Toxicon 2016, 117, 84-93. [CrossRef] [PubMed]

49. Tong, M.; Smith, J.L.; Richlen, M.; Steidinger, K.A.; Kulis, D.M.; Fux, E.; Anderson, D.M. Characterization and comparison of toxin-producing isolates of Dinophysis acuminata from New England and Canada. J. Phycol. 2015, 51, 66-81. [CrossRef] [PubMed]

50. Hattenrath-Lehmann, T.K.; Marcoval, M.A.; Mittlesdorf, H.; Goleski, J.A.; Wang, Z.; Haynes, B.; Morton, S.L.; Gobler, C.J. Nitrogenous nutrients promote the growth and toxicity of Dinophysis acuminata during estuarine bloom events. PLoS ONE 2015, 10. [CrossRef] [PubMed] 
51. Pizarro, G.; Escalera, L.; González-Gil, S.; Franco, J.M.; Reguera, B. Growth, behaviour and cell toxin quota of Dinophysis acuta during a daily cycle. Mar. Ecol. Prog. Ser. 2008, 353, 89-105. [CrossRef]

52. Pizarro, G.; Paz, B.; González-Gil, S.; Franco, J.M.; Reguera, B. Seasonal variability of lipophilic toxins during a Dinophysis acuta bloom in Western Iberia: Differences between picked cells and plankton concentrates. Harmful Algae 2009, 8, 926-937. [CrossRef]

53. Mafra, L.L.; Ribas, T.; Alves, T.P.; Proença, L.A.O.; Schramm, M.A.; Uchida, H.; Suzuki, T. Differential okadiac acid accumulation and detoxification by oysters and mussels during natural and simulated Dinophysis blooms. Fish. Sci. 2015, 81, 749-762. [CrossRef]

54. Vale, P. Differential dynamics of dinophysistoxins and pectenotoxins between blue mussel and common cockle: A phenomenon originating from the complex toxin profile of Dinophysis acuta. Toxicon 2004, 44, 123-134. [CrossRef] [PubMed]

55. Vale, P. Differential dynamics of dinophysistoxins and pectenotoxins, part II: Offshore bivalve species. Toxicon 2006, 47, 163-173. [CrossRef] [PubMed]

56. Lindegarth, S.; Torgersen, T.; Lundve, B.; Sandvik, M. Differential retention of okadaic acid (OA) group toxins and pectenotoxins (PTX) in the blue mussel, Mytilus edulis (L.) and European flat oyster, Ostrea edulis (L.). J. Shellfish Res. 2009, 28, 313-323. [CrossRef]

57. García-Altares, M.; Casanova, A.; Fernández-Tejedor, M.; Diogène, J.; de la Iglesia, P. Bloom of Dinophysis spp. dominated by D. sacculus and its related diarrhetic shellfish poisoning (DSP) outbreak in Alfacs Bay (Catalonia, NW Mediterranean Sea): Identification of DSP toxins in phytoplankton, shellfish and passive samplers. Reg. Stud. Mar. Sci. 2016, 6, 19-28. [CrossRef]

58. Hattenrath-Lehmann, T.K.; Lusty, M.W.; Wallace, R.B.; Haynes, B.; Wang, Z.; Broadwater, M.; Deeds, J.R.; Morton, S.L.; Hastback, W.; Porter, L.; et al. Evaluation of rapid, early warning approaches to track shellfish toxins associated with Dinophysis and Alexandrium blooms. Mar. Drugs 2018, 16. [CrossRef] [PubMed]

59. MacKenzie, L.; Beuzenberg, V.; Holland, P.; McNabb, P.; Suzuki, T.; Selwood, A. Pectenotoxin and okadaic acid-based toxin profiles in Dinophysis acuta and Dinophysis acuminata from New Zealand. Harmful Algae 2005, 4, 75-85. [CrossRef]

60. Suzuki, T.; Miyazono, A.; Baba, K.; Sugawara, R.; Kamiyama, T. LC-MS/MS analysis of okadaic acid analogues and other lipophilic toxins in single-cell isolates of several Dinophysis species collected in Hokkaido, Japan. Harmful Algae 2009, 8, 233-238. [CrossRef]

61. Kamiyama, T.; Suzuki, T. Production of dinophysistoxin-1 and pectenotoxin-2 by a culture of Dinophysis acuminata (Dinophyceae). Harmful Algae 2009, 8, 312-317. [CrossRef]

62. Blanco, J.; Álvarez, G.; Uribe, E. Identification of pectenotoxins in plankton, filter feeders and isolated cells of a Dinophysis acuminata with an atypical toxin profile from Chile. Toxicon 2007, 49, 710-716. [CrossRef] [PubMed]

63. Fux, E.; Smith, J.L.; Tong, M.; Guzmán, L.; Anderson, D.M. Toxin profiles of five geographical isolates of Dinophysis spp. from North and South America. Toxicon 2011, 57, 275-287. [CrossRef] [PubMed]

64. Fabro, E.; Almandoz, G.O.; Ferrario, M.; Tillmann, U.; Cembella, A.; Krock, B. Distribution of Dinophysis species and their association with lipophilic phycotoxins in plankton from the Argentine Sea. Harmful Algae 2016, 59, 31-41. [CrossRef] [PubMed]

65. Lindahl, O.; Lundve, B.; Johansen, M. Toxicity of Dinophysis spp. in relation to population density and environmental conditions on the Swedish west coast. Harmful Algae 2007, 6, 218-231. [CrossRef]

66. Jørgensen, K.; Andersen, P. Relation between the concentration of Dinophysis acuminata and diarrheic shellfish poisoning toxins in blue mussels (Mytilus edulis) during a toxic episode in the Limfjord (Denmark), 2006. J. Shellfish Res. 2007, 26, 1081-1087. [CrossRef]

67. Nielsen, L.T.; Krock, B.; Hansen, P.J. Effects of light and food availability on toxin production, growth and photosynthesis in Dinophysis acuminata. Mar. Ecol. Prog. Ser. 2012, 471, 37-50. [CrossRef]

68. Fernández, M.L.; Reguera, B.; Ramilo, I.; Martinez, A. Toxin content of Dinophysis acuminata, D. acuta and D. caudata from the Galician Rías Baixas. In Proceedings of the Ninth Conference on Harmful Algal Blooms, Hobart, Australia, 7-11 February 2000; Hallegraeff, G.M., Blackburn, S.I., Bolch, C.J., Lewis, R.J., Eds.; Intergovernmental Oceanographic Commission of UNESCO: Paris, France, 2001; pp. 360-363.

69. Vale, P.; de M Sampayo, M.A. Dinophysistoxin-2: A rare diarrhoeic toxin associated with Dinophysis acuta. Toxicon 2000, 38, 1599-1606. [CrossRef] 
70. Marcaillou, C.; Gentien, P.; Lunven, M.; Le Grand, J.; Mondeguer, F.; Danilou, M.M.; Crassous, M.P.; Youenou, A. Dinophysis acuminata distribution and specific toxin content in relation to mussel contamination. In Proceedings of the Ninth Conference on Harmful Algal Blooms, Hobart, Australia, 7-11 February 2000; Hallegraeff, G.M., Blackburn, S.I., Bolch, C.J., Lewis, R.J., Eds.; Intergovernmental Oceanographic Commission of UNESCO: Paris, France, 2001; pp. 356-358.

71. James, K.J.; Bishop, A.G.; Healy, B.M.; Roden, C.; Sherlock, I.R.; Twohig, M.; Draisci, R.; Giannetti, L.; Lucentini, L. Efficient isolation of the rare diarrhoeic shellfish toxin, dinophysistoxin-2, from marine phytoplankton. Toxicon 1999, 37, 343-357. [CrossRef]

72. Puente, P.F.; Sáez, M.J.F.; Hamilton, B.; Furey, A.; James, K.J. Studies of polyether toxins in the marine phytoplankton, Dinophysis acuta, in Ireland using multiple tandem mass spectrometry. Toxicon 2004, 44, 919-926. [CrossRef] [PubMed]

73. Fux, E.; Gonzalez-Gil, S.; Lunven, M.; Gentien, P.; Hess, P. Production of diarrhetic shellfish poisoning toxins and pectenotoxins at depths within and below the euphotic zone. Toxicon 2010, 56, 1487-1496. [CrossRef] [PubMed]

74. Morris, S.; Stubbs, B.; Cook, A.; Milligan, S.; Quilliam, M.A. The First Report of the Co-Occurrence of Pectenotoxins, Okadaic Acid and Dinophysistoxin-2 in Shellfish from England. Cefas Publication. 2004. Available online: https:/ / www.cefas.co.uk/publications/posters/30830web.pdf (accessed on 2 June 2018).

75. Edwards, A.; Sharples, F. Scottish sea lochs: A catalogue. Scottish Marine Biological Association. Nat. Conserv. Counc. 1986, 110, 250.

76. Bresnan, E.; Cook, K.B.; Hughes, S.L.; Hay, S.J.; Smith, K.; Walsham, P.; Webster, L. Seasonality of the plankton community at an east and west coast monitoring site in Scottish waters. J. Sea Res. 2015, 105, 16-29. [CrossRef]

77. O'Brien, T.D.; Wiebe, P.H.; Falkenhaug, T. ICES Cooperative Research Report. 2013. Available online: http:/ / ices. dk/sites/pub/PublicationReports /CooperativeResearchReport(CRR)/crr318/CRR318Zooplankton.pdf (accessed on 12 June 2018).

78. Bresnan, E.; Cook, K.; Hindson, J.; Hughes, S.; Lacaze, J.-P.; Walsham, P.; Webster, L.; Turrell, W.R. The Scottish Coastal Observatory 1997-2013: Part 1-Executive Summary. Available online: https:/ /www.gov. scot/Resource/0051/00513827.pdf (accessed on 26 September 2018).

79. Edwards, A.; Baxter, M.S.; Ellett, D.J.; Martin, J.H.A.; Meldrum, D.T.; Griffiths, C.R. Clyde Sea hydrography. Proc. R. Soc. Edinburgh Sect. B Biol. Sci. 1986, 90, 67-83.

80. Utermöhl, H. Zur Vervollkommnung der quantitativen Phytoplankton-Methodik. Mitt. Int. Ver. Theor. Angew. Limnol. 1958, 9, 1-3.

81. In-House Validation of an LC-MS/MS Method for the Determination of Lipophilic Toxins in Shellfish Species Typically Tested in the United Kingdom. Available online: https:/ /www.food.gov.uk/sites/default/files/ media/document/fs235004_0.pdf (accessed on 26 September 2018).

82. EU-Harmonised Standard Operating Procedure for Determination of Lipophilic Marine Biotoxins in Molluscs by LC-MS/MS. Available online: http:/ /www.aecosan.msssi.gob.es/AECOSAN/docs/documentos/laboratorios / LNRBM/ARCHIVO2EU-Harmonised-SOP-LIPO-LCMSMS_Version5.pdf (accessed on 8 June 2018).

83. Turner, A.D.; Goya, A.B. Occurrence and profiles of lipophilic toxins in shellfish harvested from Argentina. Toxicon 2015, 102, 32-42. [CrossRef] [PubMed]

(C) 2018 by the authors. Licensee MDPI, Basel, Switzerland. This article is an open access article distributed under the terms and conditions of the Creative Commons Attribution (CC BY) license (http://creativecommons.org/licenses/by/4.0/). 